\title{
Chemical composition, fractionation of carbohydrates and nitrogen compounds, ruminal degradation kinetics, and in vitro gas production of cactus pear genotypes
}

\section{Composição química, fracionamento de carboidratos e compostos nitrogenados, cinética da degradação ruminal e produção de gás in vitro de genótipos de palma forrageira}

\author{
André Luiz Rodrigues Magalhães ${ }^{1}$ (D) , Ana Lúcia Teodoro ${ }^{2}$ (D) , Leandro Pereira de \\ Oliveira $^{3}$ (D), Glayciane Costa Gois ${ }^{4 *}(\mathbb{D})$, Fleming Sena Campos ${ }^{1} \mathbb{D}$, Albericio Pereira de \\ Andrade $^{1}\left(\mathbb{D}\right.$, Airon Aparecido Silva de Melo ${ }^{1} \mathbb{D}$, Daniel Bezerra do Nascimento ${ }^{1}$ (D) , \\ Wanderson Alves da Silva ${ }^{5}$ \\ 'Universidade Federal Rural de Pernambuco (UFRPE), Garanhuns, PE, Brazil \\ 2 Institututo Federal de Educação, Ciência e Tecnologia do Piauí (IFPI), Corrente, PI, Brazil \\ ${ }^{3}$ Universidade Federal da Paraíba (UFPB), Areia, PB, Brazil \\ ${ }^{4}$ Universidade Federal do Vale do São Francisco (UNIVASF), Petrolina, PE, Brazil \\ ${ }^{5}$ Universidade Federal de Alagoas (UFAL), Arapiraca, AL, Brazil \\ ${ }^{*}$ Correspondent: glayciane_gois@yahoo.com.br
}

Received

June 16, 2021.

Accepted

August 16, 2021.

Published

September 20, de 2021.

www.revistas.ufg.br/vet visit the website to get the how to cite in the article page.

\section{Abstract}

The aim of this study was to evaluate the chemical composition, fractionation of carbohydrates and nitrogen compounds, degradation parameters, and in vitro ruminal fermentation of cactus pear genotypes. The experiment was conducted in a completely randomized design with 4 cactus pear genotypes and 4 replicates. The evaluated cactus pear genotypes were: Miúda (Nopalea cochenillifera Salm Dyck), IPA Sertânia (Nopalea cochenillifera), Gigante (Opuntia ficus indica Mill), and Orelha de Elefante Mexicana (Opuntia stricta Haw), all in natura. Samples were randomly collected at different points in the experimental area. Whole plants were collected 24 months after field crop establishment. $N$. cochenillifera Salm Dyck presented the highest dry matter, acid detergent insoluble protein, non-fibrous carbohydrate, total digestible nutrients, digestible energy, total carbohydrates, and fractions $A+B 1(P<0.05)$, while presenting lower neutral detergent fiber corrected for ash and protein, acid detergent fiber, and cellulose in relation to the other genotypes studied $(\mathrm{P}<0.05)$. The in vitro true digestibility of neutral detergent fiber was high for the genotypes $N$. cochenillifera Salm Dyck and $N$. cochenillifera Dyck, which also presented high in vitro total gas production $(P<0.05)$. The cactus pear genotypes show adequate chemical characteristics to be composed part of diets offered to ruminants. However, supplementation is necessary to increase the dry matter and fiber contents. The Nopalea cochenillifera Salm Dyck genotype presented the highest proportions of total digestible nutrients, non-fibrous carbohydrates, non-protein nitrogen, unavailable nitrogen fraction total, and high gas 
production in relation to the other analyzed genotypes 24 months after field crop establishment.

Keywords: Degradability; Digestibility; in vitro fermentation; Nopalea; Opuntia.

\begin{abstract}
Resumo
Objetivou-se avaliar a composição química, fracionamento de carboidratos e compostos nitrogenados, parâmetros de degradação e fermentação ruminal in vitro de genótipos de palma forrageira. O experimento foi conduzido em delineamento inteiramente casualizado, com 4 genótipos de palma forrageira e 4 repetições. Os genótipos de palma forrageira avaliadas foram: Miúda (Nopalea cochenillifera Salm Dyck), IPA Sertânia (Nopalea cochenillifera), Gigante (Opuntia ficus indica Mill), e Orelha de Elefante Mexicana (Opuntia stricta Haw), todas in natura. As amostras foram coletadas aleatoriamente em pontos distintos na área experimental. Plantas inteiras foram coletadas 24 meses após o estabelecimento da cultura de campo. N. cochenillifera Salm Dyck apresentou os maiores teores de matéria seca, proteína insolúvel em detergente ácido, carboidratos não fibrosos, nutrientes digestíveis totais, energia digestível, carboidratos totais e fração A + B1 e menores teores de fibra em detergente neutro corrigida para cinza e proteína, fibra em detergente ácido e celulose $(P<0,05)$. A digestibilidade da fibra em detergente neutro verdadeira in vitro foi elevada para os genótipos $N$. cochenillifera Salm Dyck e $N$. cochenillifera Dyck, que também apresentaram altos valores de produção de gás in vitro $(P<0,05)$. Os genótipos de palma forrageira apresentam características químicas adequadas para compor dietas oferecidas aos ruminantes, no entanto, é necessário uma suplementação para aumentar os teores de matéria seca e fibra. Nopalea cochenillifera Salm Dyck apresenta as maiores proporções de nutrientes digestíveis totais, carboidratos não fibrosos, nitrogênio não protéico e alta produção de gases em relação aos demais genótipos analisados aos 24 meses após o estabelecimento do palmal. Palavras-chave: Degradabilidade; Digestibilidade; Fermentação in vitro; Nopalea; Opuntia
\end{abstract}

\title{
Introduction
}

The Brazilian semiarid region covers an area of 969,589.4 km² approximately, which corresponds to $11.39 \%$ of the Brazilian territory ${ }^{(1)}$. The Brazilian Northeast has $70 \%$ of its area included in the semiarid, being characterized by low rainfall, which hinders the establishment of agricultural activities ${ }^{(2)}$. Under these conditions, the local vegetation tends to decrease or cease their biomass production, while at the same time reducing its nutritional value in most cases. Thus, the resource supply becomes irregular, making 
food production for livestock the main challenge in this region ${ }^{(3)}$. Therefore, it becomes necessary to optimize resources to ensure the food supply, especially during times of scarcity.

Cactus pear has been an alternative widely used by farmers for being energy-rich, having good adaptability, and displaying a high potential for biomass production in the semiarid conditions ${ }^{(4)}$. Cactus pear genotypes belonging to the genus Opuntia sp. and Nopalea sp. have anatomical and physiological characteristics and properties that allow their growth and development in dryland regions and poor soils(5). Alves et al.(6) estimated that, in the national territory, approximately 147.439 ha are cultivated with the Opuntia fícus-indica Mill (cv. Gigante, Redonda, and Clone IPA-20), Opuntia stricta Haw (cv. Orelha de Elefante Mexicana), Nopalea cochenillifera (cv. and IPA-Sertânia), and Nopalea cochenillifera Salm Dyck (Miúda). These genotipes are used for production of fruits and vegetables, human consumption, animal feed, soil conservation, biomass for energy, cochineal for carmine production, and as an ingredient in the composition of drinks, medicines, and cosmetics ${ }^{(1)}$.

One of the main attributes of cactus pear is its high water content $\left(89 \%{ }^{(7)}\right)$. Thus, this food represents a strategic reserve for the conservation of water offered to ruminants in that region, which constantly suffers from irregularities in drinking water availability for these animals ${ }^{(1)}$. Moreover, it has low neutral detergent fiber (304 g/kg dry matter) and acid detergent fiber contents $\left(159.7 \mathrm{~g} / \mathrm{kg}\right.$ dry matter) ${ }^{(7)}$ and a high non-fiber carbohydrate content $\left(471.5 \mathrm{~g} / \mathrm{kg}\right.$ dry matter $\left.r^{(8)}\right)$. Although it is a food routinely used for ruminant feed in the Brazilian Semiarid, to the best of our knowledge, comparative studies on fractions of carbohydrates, nitrogen compounds, and the kinetic parameters of in vitro degradation of different varieties of cactus pear are scarce ${ }^{(9,10)}$.

The determination of the fractions of carbohydrates and proteins and the kinetic parameters of ruminal degradation is of utmost importance for animal nutritionist ${ }^{(11)}$. This information can be used in modern formulations of diets for ruminants, maximizing the synchronization of the degradation of carbohydrates and nitrogen compounds, minimizing energy and nitrogen losses due to ruminal fermentation, and promoting a greater efficiency of microbial synthesis ${ }^{(12)}$.

The aim of this study was to evaluate the chemical composition, fractionation of carbohydrates and nitrogen compounds, degradation parameters, and in vitro ruminal fermentation of cactus pear varieties available for ruminants in the Brazilian Semiarid region.

\section{Material and methods}

\section{Laboratory analysis}

The laboratory analysis was carried out at the Federal Rural University of Pernambuco, academic Unit of Garanhuns (UFRPE - UAG), in Garanhuns, Pernambuco, Brazil, located in the Agreste Meridional mesoregion of Pernambuco (8 53 '25" S, 36 29' 34" W, altitude of 896 meters above sea level). The region's climate is classified as tropical type Aw', according Köppen and Geiger ${ }^{(13)}$ climate classification, with an annual average temperature of $21.2^{\circ} \mathrm{C}$ and annual average rainfall of $897 \mathrm{~mm}$, with the rainiest months 
being May, June, July, and August. The region is characterized by hot and dry summers and mild and humid winters, with relative humidity ranging from 75 to $83 \%$. The region's soil is classified as a typical eutrophic Regolitic Neosol(14).

\section{Samples and experimental design}

The experiment was conducted in a completely randomized design with four cactus pear genotypes (treatments) and 4 replicates per genotype. The cactus pear genotypes evaluated were: Nopalea cochenillifera Salm Dyck, Nopalea cochenillifera Dyck, Opuntia ficus indica Mill, and Opuntia stricta Haw, all in natura. The samples were collected at the Experimental Station of São Bento do Una, Pernambuco, Brazil, which belongs to the Agronomic Institute of Pernambuco (IPA), located in the mesoregion of Vale do Ipojuca $\left(8^{\circ} 31^{\prime} 16^{\prime \prime} \mathrm{S}, 36^{\circ} 33^{\prime} 0^{\prime \prime} \mathrm{W}\right.$, altitude of 614 meters above sea level). The region's climate is classified, according to Köppen and Geiger ${ }^{(13)}$, as BSwh' (Tropical Semi-arid, hot and dry), with rains concentrated in Summer and the highest rainfall occurring between January and March. The dry season starts in May and lasts until December, and the lowest rainfall is observed in September and October. The region's soil is classified as a Regolitic Neosol(14). The annual average rainfall in the year of collection was $700.8 \mathrm{~mm}$.

The samples were collected randomly from four different points in the cultivation fields (approximately $0.5 \mathrm{ha}$ ) of each genotype of cactus pear, consisting of four replicates per sample of each genotype. The border plants (two external lines) of each cultivation plot and plants established at the ends of the intermediate lines were disregarded during collection. Whole plants were collected (about $5 \mathrm{~cm}$ from ground level) 24 months after the field crop establishment.

\section{Sample preparation for analysis}

The cactus pear genotypes were chopped manually using a knife, homogenized manually, and the material was distributed in plastic trays. Samples were pre-dried in a forced air ventilation oven at $55^{\circ} \mathrm{C}$ for $72 \mathrm{~h}$ and ground to $1-\mathrm{mm}$ and $2 \mathrm{~mm}$-sized particles (Wiley mill, Marconi, MA - 580, Piracicaba, Brazil) to determine the chemical composition, gas production, degradability, and in vitro digestibility assays.

\section{Chemical analysis}

All chemical analyses were carried out using the procedures described by the $\mathrm{AOAC}^{(15)}$ for dry matter (DM, method 967.03), organic matter (OM), mineral matter (MM, method 942.05), ether extract (EE, method 920.29), and crude protein (CP, method 981.10). Neutral detergent fiber (NDF) and acid detergent fiber (ADF) were determined according to the methodology proposed by Van Soest et al.(16). Neutral detergent fiber corrected for ash and protein (NDFap) was determined using thermo-stable alphaamylase without addition of sodium sulfite ${ }^{(17,18)}$ and lignin was determined by treating the acid detergent fiber residue with $72 \%$ sulfuric acid(19). The pectin was quantified according to Canteri-Shemin et al. ${ }^{(20)}$ with changes by Zanella and Taranto(21). The fractions of cellulose (CEL) and hemicellulose (HEM) were estimated by the equations: $\mathrm{CEL}=\mathrm{ADF}-\mathrm{LIG}$ and $\mathrm{HEM}=\mathrm{NDF}-\mathrm{ADF}$.

\section{Carbohydrate fractionation}

Total carbohydrates (TC) were measured using the equation proposed by Sniffen et al. ${ }^{(22)}$, as follows: TC $(\% \mathrm{DM})=100-(\mathrm{CP}+\mathrm{EE}+\mathrm{MM})$. Non-fibrous carbohydrate (NFC), 
corresponding to the fractions $\mathrm{A}+\mathrm{B} 1$, was measured by the equation: NFC $=100-(\mathrm{CP}+$ NDFap + EE + MM). The fraction B2 (digestible fiber) was obtained by the difference between the total carbohydrates of NDFap and the fraction C (indigestible fiber). The fraction C was obtained by the indigestible NDF after 288 hours in situ incubation, as described by Huhtanen et al. ${ }^{(23)}$.

\section{Nitrogen compounds}

The levels of non-protein nitrogen (NPN), neutral detergent insoluble nitrogen (NDIN), and acid detergent insoluble nitrogen (ADIN) were determined according to Licitra et al. ${ }^{(17)}$. Protein fractionation was calculated by the CNCPS system ${ }^{(22)}$. The protein was analyzed and calculated for the five fractions: A, B1, B2, B3, and C. The fraction A, consisting of NPN compounds, was determined by the difference between total $\mathrm{N}$ and trichloroacetic acid (TCA) insoluble nitrogen by the equation: $\mathrm{A}(\% \mathrm{Nt})=\mathrm{Nt}-\mathrm{N} 1 / \mathrm{Nt} \times 100$, where: $\mathrm{Nt}=$ total nitrogen of the sample, and $\mathrm{N} 1=$ content of trichloroacetic acidinsoluble nitrogen.

The fraction B1 refers to soluble protein rapidly degraded in the rumen, and obtained by the difference between the borate phosphate buffer (BPB) insoluble nitrogen minus the NPN by the equation: B1 (\% Nt) = N1 - N2/Nt x 100, where: N2 = borate phosphate buffer insoluble nitrogen. The fractions B2 and B3 consist of insoluble protein with intermediate-slow degradation rate in rumen, determined by the difference between the borate phosphate buffer insoluble nitrogen and NDIN and the NDIN minus the ADIN, respectively. The value of B2 is achieved with: B2 (\% Nt) = N2 - NIDN/Nt x 100, and the value of fraction $B 3$ is achieved with: $B 3(\% \mathrm{Nt})=\mathrm{NDIN}-\mathrm{ADIN} / \mathrm{Nt} \times 100$. The fraction $C$ is formed by insoluble protein, indigestible in the rumen and intestine. It was determined by the content of residual nitrogen of the sample after treated with acid detergent, expressed in percentage of $\mathrm{Nt}$ of the sample.

Total digestible nutrients (TDN) were estimated according to the NRC ${ }^{(24)}$ by the equation: $\% \mathrm{TDN}=\mathrm{NFCd}+\mathrm{CPd}+($ FAd $\times 2.25)+\mathrm{NDFdn}-7$, where 7 is the metabolic fecal TDN; NFCd are digestible non-fiber carbohydrates; CPd is digestible crude protein; FAd are digestible fatty acids; and NDFdn is NDF corrected for digestible nitrogen. NFCd was calculated by the equation: NFCd $=0.98 \times[100-(\% \mathrm{CP}+\% \mathrm{EE}+\% \mathrm{NDFdn}+\% \mathrm{MM})] \times \mathrm{PAF}_{\text {, }}$ where PAF is an adjustment factor equal to 1 for all genotypes, according to the $\mathrm{NRC}^{(24)}$. To calculate $C P d$ and $F A d$, the following equations were used: $C P d=C P-\exp ^{[-1.2 \times(A D P / C P)]}$ and $\mathrm{FAd}=\mathrm{EE}-1$, assuming feed with EE contents $<1$ and FAd $=0$. The NFDd was obtained using an in vitro degradability assay for 48 hours, according to the $N R C^{(24)}$. Digestible energy $(\mathrm{DE})$ was estimated by the equation: $\mathrm{DE}=(\mathrm{NFCd} / 100) \times 4.2+(\mathrm{NDFd} /$ 100) $\times 4.2+(\mathrm{CPd} / 100) \times 5.6+(\mathrm{FAd} / 100) \times 9.4-0.3^{(24)}$.

\section{Ruminal degradation kinetics by in vitro gas production}

Degradability was determined in accordance with Tilley and Terry ${ }^{(25)}$ through in vitro incubations of $600 \mathrm{mg}$ of air-dried sample with $60 \mathrm{~mL}$ of buffer solution (combination of solutions $\mathrm{A}+\mathrm{B}$ with $\mathrm{pH}$ 6.8) and $15 \mathrm{~mL}$ of inoculum collected from two rumenfistulated goats, which was filtered in four layers of gauze and received a constant injection of carbon dioxide to maintain the anaerobic environment. It was incubated at $0,3,6,9,12,18,24,36$, and 48 hours. Time 0 samples were only washed with distilled water at $39^{\circ} \mathrm{C}$. At the other times, samples were incubated in an incubator at a constant 
temperature of $39^{\circ} \mathrm{C}$.

For in vitro true dry matter digestibility (IVTDMD), the two-stage methodology described by Tilley and Terry ${ }^{(25)}$ was used considering the changes proposed by Holden ${ }^{(26)}$ through in vitro incubations of $1 \mathrm{~g}$ of air-dried sample with $80 \mathrm{~mL}$ of buffer solution and $20 \mathrm{~mL}$ of ruminal fluid, which was filtered in four layers of gauze and received a constant injection of carbon dioxide to maintain the anaerobic environment. After 48 hours of incubation, $6 \mathrm{~mL}$ of $20 \%$ hydrochloric acid $(\mathrm{HCl})$ and $2 \mathrm{~mL}$ of pepsin (1:1000) were added into each vial and, after the period of 24 hours of incubation, the filtration procedures were performed (vacuum process, drying, and weighing of the waste) in order to calculate the IVTDMD.

In vitro degradation parameters $(\mathrm{a}, \mathrm{b}$, and $\mathrm{c})$ and potential dry matter degradability were estimated using the model, proposed by Ørskov and McDonald ${ }^{(27)}$ : PD $=a+b\left(1-e^{-c t}\right)$ using the PROC NLIN procedure of the SAS software, where "PD" is the actual percentage of nutrient degraded after t hours of incubation, "a" is the readily soluble fraction, " $b$ " is the fraction that can be degraded if there is time, "c" is b fraction degradation rate or speed, and " $\mathrm{t}$ " is incubation time. To estimate the effective degradability (ED), the following equation was used: $E D=a+(b * c) /(c+k)$, where $k$ is the food passage rate. The passage rates of rumen particles are estimated at $0.02,0.05$, and $0.08 \mathrm{~h}^{-1}$, as suggested by the AFRC ${ }^{(28)}$.

For in vitro gas production, $1.0 \mathrm{~g}$ of sample was added to glass bottles (160 mL) to which $90 \mathrm{~mL}$ of nutrient medium were added, according to Theodorou et al. ${ }^{(29)}$. Subsequently, $10 \mathrm{~mL}$ of rumen fluid (from the rumen of three goats) was added to each vial, which were maintained under $\mathrm{CO}_{2}$ aspersion. Then, the vials were sealed with rubber corks and aluminum seals. The pressure caused by fermentation was measured using a pressure transducer (Data logger Universal Logger AG100). The readings were made with a higher rate during the initial period and at a lower rate towards the end of the study period $(2,4,6,8,10,12,15,18,21,24,30,36,42$, and 48 hours of incubation). Pressure data $(P)$ in psi (pressure per square inch) were converted into gas volume (V) by the equation: $V=5.1612 P-0.3017, R^{2}=0.9873$, generated in the Production Laboratory (LPG) of the Academic Unit of Garanhuns, UFRPE, based on 937 observations (-8 $90^{\prime} 77^{\prime \prime} \mathrm{S},-36^{\circ} 49^{\prime} 49^{\prime \prime} \mathrm{W}$, altitude of 844 meters), 1 psi $=4.859 \mathrm{~mL}$ of gas. From each pressure reading, the total produced by the bottles without substrate (white), for each sample, was subtracted.

Cumulative gas production data were analyzed using the Gompertz two-compartment model, cited by Schofield et al. (30), using the NLMIXED procedure of SAS (version 9.3, SAS Institute Inc., Cary, North Carolina, USA)(31): V(t) $=\mathrm{Vf1} /\left[11+\mathrm{e}^{(2-4 \mathrm{Kd} 1(\mathrm{~L}-\mathrm{T}))}\right]+\mathrm{Vf} 2 /\left[1+\mathrm{e}^{(2-4 \mathrm{Kd} 2(\mathrm{~L}-}\right.$ $\mathrm{T})$ ) ], where: $\mathrm{V}(\mathrm{t})=$ total maximum volume of gas produced; $\mathrm{Vf1}$ = maximum volume of gas for the fast digesting fraction (non-fiber carbohydrates; NFC); Vf2 = maximum volume of gas for the slow digesting fraction (fibrous carbohydrates; FC); Kd1 = specific growth rate for the rapid degradation fraction; $\mathrm{Kd} 2=$ specific growth rate for the slow degradation fraction; $L=$ duration of initial digestion events (latency time), common to both phases, and; $T$ = fermentation time (hours).

The Gompertz two-compartment model was chosen assuming that the gas production rate is proportional to the microbial activity, but the proportionality decreases with the incubation time, which can be attributed to the loss of efficiency in the fermentation 
rate with time ${ }^{(30)}$.

\section{Statistical analysis}

Data were subjected to Shapiro-Wilk and Levene tests to check the normality of the residues and the homogeneity of the variances, respectively; once the assumptions were met, they were tested by analysis of variance using the general procedures of linear models (PROC GLM). In vitro fermentation kinetics data were analyzed using the mixed non-linear procedure (PROC NLMIXED) and were estimated by the least-squares method using the iterative Gauss Newton process. Fermentation parameters were generated from data observed at different in vitro incubation times. All data were compared by Tukey test at the $5 \%$ significance level using the software Statistical Analysis System ${ }^{(31)}$.

\section{Results}

The cactus pear of genotype $N$. cochenillifera Salm Dyck presented the highest contents of DM ( $P<0.001)$, ADIP $(P<0.001)$, NFC $(P<0.001)$, TDN $(P=0.008)$, and $D E(P=0.003)$, and lower contents of NDFap, ADF, and CEL (Table 1). OM and pectin contents were higher for the genotypes $N$. cochenillifera Salm Dyck and O. ficus indica Mill $(P<0.05)$. NDFap contents were higher $(P<0.05)$ for the genotype 0 . ficus indica Mill and lower $(P<0.05)$ for the genotype N. cochenillifera Salm Dyck. As for ADF, there were variations from 102.9 g/kg DM for N. cochenillifera Salm Dyck to 188.4 g/kg DM for O. ficus indica Mill (Table 1). The ADL content was higher for the genotype O. ficus indica Mill, although being low for all genotypes $(P<0.05$; Tabela 1$)$. For $M M$, higher values were found for the genotypes $O$. stricta Haw and N. cochenillifera Dyck ( $P<0,05$; Tabela 1). No differences were found for EE contents ( $P=0.890$; Tabela 1).

The cactus pear of the $N$. cochenillifera Salm Dyck genotype showed a higher proportion of total carbohydrates $(P=0.0011)$ and fraction $A+B 1(P<0.001)$ (Table 2). The genotype 0 . ficus indica Mill presented the highest $(P<0.05)$ concentration of the fraction $B 2$ (potentially digestible fiber) $(P<0.001)$. As for the fraction $C$, the highest values were observed for the genotype 0 . stricta Haw ( $P<0.001$; Table 2). The highest content of crude protein was observed for the genotypes 0 . ficus indica Mill and O. stricta Haw in relation to Nopalea cochenillifera Salm Dyck, not differing from Nopalea cochenillifera Dyck $(P=0.003)$. For the fractionation of nitrogen compounds, the genotype $N$. cochenillifera Salm Dyck presented the highest concentration of fractions $A(P=0.001)$ and $C(P<0.001)$ (Table 2$)$. Higher concentrations of the fraction $B 1+B 2$, corresponding to high and average fractions of rumen degradation, were observed for the genotypes O. stricta Haw and N. cochenillifera Dyck ( $P<0.001$; Table 2). The genotype O. ficus indica Mill presented the highest content of fraction B3 ( $P<0.001$; Table 2$)$. 
Table 1. Chemical composition of cactus pear genotypes

\begin{tabular}{|c|c|c|c|c|c|c|}
\hline \multirow[b]{2}{*}{ Variables } & \multicolumn{4}{|c|}{ Cactus pear genotypes } & \multirow[b]{2}{*}{ SEM } & \multirow[b]{2}{*}{$P$ value } \\
\hline & $\begin{array}{l}\text { Nopalea } \\
\text { cochenillife } \\
\text { ra Salm } \\
\text { Dyck }\end{array}$ & $\begin{array}{l}\text { Opuntia } \\
\text { ficus indica } \\
\text { Mill }\end{array}$ & $\begin{array}{l}\text { Opuntia } \\
\text { stricta Haw }\end{array}$ & $\begin{array}{c}\text { Nopalea } \\
\text { cochenillifera } \\
\text { Dyck }\end{array}$ & & \\
\hline DM (g/kg FM) & $138.1 \mathrm{a}$ & $95.6 b$ & $52.5 d$ & $70.1 \mathrm{c}$ & 8.57 & $<0.001$ \\
\hline MM (g/kg DM) & $110.2 b$ & $122.4 \mathrm{~b}$ & 159.9a & 167.3a & 7.27 & 0.008 \\
\hline OM (g/kg DM) & $889.8 a$ & $877.6 a$ & $840.1 b$ & $832.7 b$ & 7.27 & 0.008 \\
\hline EE (g/kg DM) & 9.2 & 10.2 & 8.8 & 8.6 & 0.72 & 0.890 \\
\hline NDIP (g/kg CP) & $567.6 b$ & $756.0 a$ & $374.7 c$ & $311.2 c$ & 46.9 & $<0.001$ \\
\hline ADIP (g/kg CP) & $353.8 a$ & $183.3 b$ & $200.7 b$ & $187.6 \mathrm{~b}$ & 19.19 & $<0.001$ \\
\hline NFC (g/kg DM) & $728.0 a$ & $587.8 b$ & $602.2 b$ & $617.8 b$ & 15.86 & $<0.001$ \\
\hline PEC (g/kg DM) & $382.5 a$ & $312.6 a$ & 155.6b & $223.5 b$ & 23.6 & $<0.001$ \\
\hline NDFap (g/kg DM) & $114.5 c$ & $204.7 a$ & $154.8 b$ & $150.5 b$ & 8.59 & $<0.001$ \\
\hline ADF (g/kg DM) & $102.9 c$ & $188.4 a$ & $139.9 b$ & $140.1 b$ & 8.13 & $<0.001$ \\
\hline CEL (g/kg DM) & $94.9 c$ & $165.9 a$ & $128.6 b$ & $133.8 b$ & 6.42 & $<0.001$ \\
\hline ADL (g/kg DM) & $8.0 c$ & $22.5 a$ & $11.3 b$ & $6.3 c$ & 1.65 & $<0.001$ \\
\hline TDN (g/kg DM) & $709.4 a$ & $659.9 b$ & $650.9 b$ & $654.1 b$ & 0.62 & 0.008 \\
\hline DE (Mcal/kg DM) & $3.0 a$ & $2.9 b$ & $2.8 \mathrm{~b}$ & $2.8 \mathrm{~b}$ & 0.03 & 0.003 \\
\hline
\end{tabular}

Cactus pear genotypes: Miúda (Nopalea cochenillifera Salm Dyck), IPA Sertânia (Nopalea cochenillifera Dyck), Gigante (Opuntia ficus indica Mill) and Orelha de Elefante Mexicana (Opuntia stricta Haw); SEM Standard error of the mean; FM - Fresh matter; DM - Dry matter; MM - Mineral matter; OM - Organic matter; EE - Ether extract; CP -Crude protein; NDIP - Neutral Detergent Insoluble Protein; ADIP - Acid Detergent Insoluble Protein; NFC - Non fibrous carbohydrates; PEC - Pectin; NDFap - Neutral detergent fiber corrected for ash (a) and protein (p); ADF - Acid detergent fiber; CEL - Cellulose; ADL - Acid detergent lignin; TDN - total digestible nutrients; DE - Digestible energy; Means followed by distinct letters differ statistically by the Tukey's test $(P<0.05)$. 
Chemical composition, fractionation of carbohydrates and nitrogen compounds, ruminal degradation..

Magalhães A L R et al.

Table 2. Carbohydrates fractionation and nitrogen compounds of cactus pear genotypes

\begin{tabular}{|c|c|c|c|c|c|c|}
\hline \multirow[b]{2}{*}{ Variables } & \multicolumn{4}{|c|}{ Cactus pear genotypes } & \multirow[b]{2}{*}{ SEM } & \multirow[b]{2}{*}{$P$ value } \\
\hline & $\begin{array}{c}\text { Nopalea } \\
\text { cochenillifera } \\
\text { Salm Dyck }\end{array}$ & $\begin{array}{l}\text { Opuntia } \\
\text { ficus indica } \\
\text { Mill }\end{array}$ & $\begin{array}{c}\text { Opuntia } \\
\text { stricta } \\
\text { Haw }\end{array}$ & $\begin{array}{c}\text { Nopalea } \\
\text { cochenillifera } \\
\text { Dyck }\end{array}$ & & \\
\hline \multicolumn{7}{|c|}{ Carbohydrate fractionation } \\
\hline TC (g/kg DM) & $842.6 a$ & $792.5 b$ & $757.0 \mathrm{~b}$ & $768.3 b$ & 10.0 & 0.011 \\
\hline $\mathrm{A}+\mathrm{B} 1$ (g/kg TC) & $866.9 a$ & $741.7 c$ & $795.4 b$ & $803.3 b$ & 12.1 & $<0.001$ \\
\hline B2 (g/kg TC) & $101.0 c$ & 221.0a & $137.9 b$ & $159.0 b$ & 11.8 & $<0.001$ \\
\hline C (g/kg TC) & $34.9 b$ & $37.3 b$ & $66.7 a$ & $37.7 b$ & 19.2 & $<0.001$ \\
\hline \multicolumn{7}{|c|}{ Nitrogen compounds } \\
\hline $\mathrm{CP}(\mathrm{g} / \mathrm{kg} \mathrm{DM})$ & $38.1 b$ & $74.9 a$ & $74.3 a$ & $55.8 a b$ & 4.8 & 0.003 \\
\hline$A(g / k g ~ C P)$ & $213.4 a$ & $102.9 \mathrm{~b}$ & $90.9 b$ & $136.4 b$ & 13.7 & 0.001 \\
\hline $\mathrm{B} 1+\mathrm{B} 2(\mathrm{~g} / \mathrm{kg} \mathrm{CP})$ & $219.0 \mathrm{~b}$ & $141.1 \mathrm{~b}$ & $534.4 a$ & $552.4 a$ & 49.8 & $<0.001$ \\
\hline B3 (g/kg CP) & $213.8 b$ & $572.7 a$ & $173.99 b$ & $123.6 b$ & 47.0 & $<0.001$ \\
\hline C (g/kg CP) & $353.8 \mathrm{a}$ & $183.3 b$ & $200.7 b$ & $187.6 \mathrm{~b}$ & 19.2 & $<0.001$ \\
\hline
\end{tabular}

Cactus pear genotypes: Miúda (Nopalea cochenillifera Salm Dyck), IPA Sertânia (Nopalea cochenillifera Dyck), Gigante (Opuntia ficus indica Mill) and Orelha de Elefante Mexicana (Opuntia stricta Haw); SEM Standard error of the mean; Carbohydrate fractionation: TC - Total carbohydrate, A+B1 - soluble fraction, B2 - potentially degradable fiber, C - indigestible fiber. Nitrogen compounds: CP - Crude protein, A - nonprotein nitrogen, B1+B2 - high and average rumen nitrogen degradation fraction, B3 - slow nitrogen degradation fraction, $\mathrm{C}$ - unavailable nitrogen fraction; Means followed by distinct letters differ statistically by Tukey's test $(P<0.05)$.

The highest percentages of in vitro DM soluble fractions were observed for the variety 0 . stricta Haw (456.4 g/kg) in relation to other genotypes ( $(<<0.001$; Table 3$)$. The in vitro slowly degradable fraction of DM ranged from 423.2 to $640.4 \mathrm{~g} / \mathrm{kg}$ of DM with lower mean value for 0 . stricta Haw ( $<<0.001$; Table 3). The 0 . stricta Haw genotype presented higher effective degradability as a function of incubation time according to the slow, medium, and fast rates $(P<0.05$; Table 3$)$. No differences were observed between the genotypes of cactus pear for degradation rate $(c, \% / h)(P=0.070)$, potential degradation $(P=0.22)$, and in vitro true dry matter digestibility $(P=0.34)$ (Table 3$)$. 
Chemical composition, fractionation of carbohydrates and nitrogen compounds, ruminal degradation...

Magalhães A L R et al.

Table 3. Degradation parameters and in vitro digestibility of cactus pear genotypes

Variables

Cactus pear genotypes

SEM P value

\begin{tabular}{|c|c|c|c|c|c|c|}
\hline & $\begin{array}{c}\text { Nopalea } \\
\text { cochenillifera } \\
\text { Salm Dyck }\end{array}$ & $\begin{array}{l}\text { Opuntia } \\
\text { ficus } \\
\text { indica Mill }\end{array}$ & $\begin{array}{c}\text { Opuntia } \\
\text { stricta } \\
\text { Haw }\end{array}$ & $\begin{array}{c}\text { Nopalea } \\
\text { cochenillifera } \\
\text { Dyck }\end{array}$ & & \\
\hline$a(g / k g D M)$ & $262.0 b$ & $264.1 b$ & $456.4 a$ & $324.0 b$ & 21.8 & $<0.001$ \\
\hline$b(g / k g D M)$ & 604.9ab & $640.4 a$ & $423.2 \mathrm{c}$ & $565.8 b$ & 21.8 & $<0.001$ \\
\hline$c(\% / h)$ & 1.1 & 0.7 & 0.8 & 0.7 & 0.06 & 0.070 \\
\hline $\operatorname{ED}(0.02 / h)$ & $766.1 \mathrm{~b}$ & $766.0 \mathrm{~b}$ & $797.2 a$ & $754.0 \mathrm{~b}$ & 5.0 & 0.003 \\
\hline $\operatorname{ED}(0.05 / h)$ & $666.6 \mathrm{~b}$ & $643.0 \mathrm{~b}$ & $721.5 a$ & $641.4 b$ & 8.8 & $<0.001$ \\
\hline $\operatorname{ED}(0.08 / h)$ & $600.5 b$ & $568.5 c$ & $673.8 a$ & $576.0 \mathrm{bc}$ & 1.2 & $<0.001$ \\
\hline $\mathrm{Pd}(\mathrm{g} / \mathrm{kg} \mathrm{DM})$ & 866.9 & 904.5 & 879.6 & 889.8 & 6.6 & 0.220 \\
\hline IVTNDFD (g/kg NDF) & $778.1 \mathrm{a}$ & $521.4 c$ & $678.7 b$ & $814.9 a$ & 30.5 & $<0.001$ \\
\hline IVTDMD (g/kg DM) & 826.0 & 798.7 & 820.8 & 827.2 & 6.1 & 0.344 \\
\hline
\end{tabular}

Cactus pear genotypes: Miúda (Nopalea cochenillifera Salm Dyck), IPA Sertânia (Nopalea cochenillifera Dyck), Gigante (Opuntia ficus indica Mill) and Orelha de Elefante Mexicana (Opuntia stricta Haw); SEM Standard error of the mean; $a, b$ and $c$ refer to parameters of Orskov \& McDonald (1979); ED - effective degradability for a passage rate of $0.02,0.05$ and $0.08 \mathrm{~h}^{-1} ; \mathrm{Pd}$ - potential degradability represented by the sum of $a$ and $b$; IVTNDFD - in vitro true neutral detergent fiber digestibility; IVTDMD - in vitro true dry matter digestibility; Means followed by distinct letters differ statistically by Tukey's test $(P<0.05)$.

The degradation curves as a function of incubation time were similar for all cactus pear genotypes (Figure 1).

The genotype N. cochenillifera Salm Dyck showed the highest gas volume of NFC (220.6 $\mathrm{mL} / \mathrm{g} D \mathrm{DM} ; \mathrm{P}=0.008$; Table 4). Regarding latency time (L), high values were observed for the genotype N. cochenillifera Salm Dyck, O. ficus indica Mill, and N. cochenillifera Dyck, while the lowest value was observed for the genotype 0 . stricta Haw ( $P=0.001$; Table 4). 

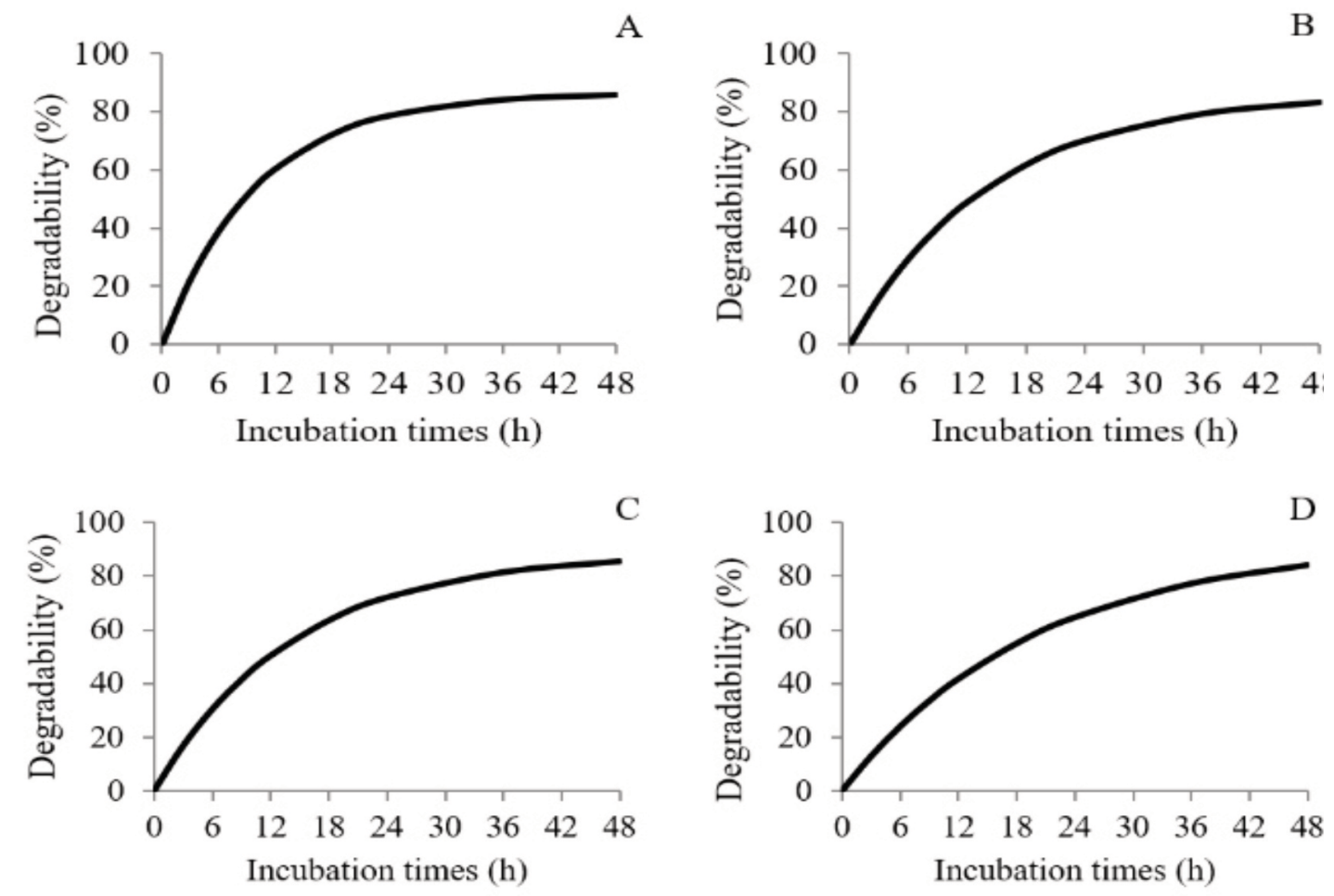

Figure 1. Dry matter degradability curves of cactus pear genotypes as a functi of in vitro incubation time (A - Nopalea cochenillifera Salm Dyck; B - Opuntia fic indica Mill; C - Opuntia stricta Haw; D - Nopalea cochenillifera Dyck).

Table 4. In vitro gas production kinetics of cactus pear genotypes

\begin{tabular}{rcccccc}
\hline \multirow{7}{*}{ Variables } & \multicolumn{7}{c}{ Cactus pear genotypes } \\
\cline { 2 - 7 } & $\begin{array}{c}\text { Nopalea } \\
\text { cochenillifera ficus indica } \\
\text { Salm Dyck }\end{array}$ & $\begin{array}{c}\text { Opuntia } \\
\text { Mill }\end{array}$ & $\begin{array}{c}\text { Opuntia } \\
\text { stricta } \\
\text { Haw }\end{array}$ & $\begin{array}{c}\text { Nopalea } \\
\text { cochenillifera } \\
\text { Dyck }\end{array}$ & SEM & P value \\
\hline $\mathrm{Vf1}(\mathrm{mL} / \mathrm{g} \mathrm{DM})$ & $220.6 \mathrm{a}$ & $174.6 \mathrm{~b}$ & $193.2 \mathrm{~b}$ & $177.9 \mathrm{~b}$ & 60.0 & 0.008 \\
$\mathrm{Kd} 1(\mathrm{~mL} / \mathrm{g} \mathrm{DM} / \mathrm{h})$ & 0.05 & 0.04 & 0.04 & 0.04 & 0.01 & 0.070 \\
$\mathrm{~L}(\mathrm{~h})$ & $3.6 \mathrm{a}$ & $3.4 \mathrm{a}$ & $2.4 \mathrm{~b}$ & $3.4 \mathrm{a}$ & 1.3 & 0.001 \\
$\mathrm{Vf} 2(\mathrm{~mL} / \mathrm{g} \mathrm{DM})$ & $115.4 \mathrm{a}$ & $99.0 \mathrm{~b}$ & $99.4 \mathrm{~b}$ & $121.7 \mathrm{a}$ & 30.3 & 0.001 \\
$\mathrm{Kd} 2(\mathrm{~mL} / \mathrm{g} \mathrm{DM} / \mathrm{h})$ & $0.14 \mathrm{~b}$ & $0.13 \mathrm{~b}$ & $0.16 \mathrm{a}$ & $0.12 \mathrm{~b}$ & 0.04 & 0.005 \\
$\mathrm{~V}(\mathrm{t})(\mathrm{mL} / \mathrm{g} \mathrm{DM})$ & $341.1 \mathrm{a}$ & $277.9 \mathrm{~b}$ & $297.7 \mathrm{~b}$ & $303.4 \mathrm{ab}$ & 72.1 & 0.003 \\
$\mathrm{~V}(\mathrm{t}) 2(\mathrm{~mL} / \mathrm{g} \mathrm{DM})$ & $336.0 \mathrm{a}$ & $273.7 \mathrm{~b}$ & $292.6 \mathrm{~b}$ & $299.6 \mathrm{ab}$ & 71.2 & 0.003 \\
\hline
\end{tabular}

Cactus pear genotypes: Miúda (Nopalea cochenillifera Salm Dyck), IPA Sertânia (Nopalea cochenillifera Dyck), Gigante (Opuntia ficus indica Mill) and Orelha de Elefante Mexicana (Opuntia stricta Haw); SEM Standard error of the mean; Vf1 - maximum volume of gas for the fast digesting fraction (non-fiber carbohydrates; NFC), Kd1 - specific growth rate for the rapid degradation fraction, L - duration of initial digestion events (latency time), common to both phases, Vf2 - maximum volume of gas for the slow digesting fraction (fibrous carbohydrates; FC), Kd2 - specific growth rate for the slow degradation fraction, $\mathrm{V}(\mathrm{t})$ - total maximum volume of gas produced, $\mathrm{V}(\mathrm{t}) 2$ - total gas production by adjusting the twocompartment model $(\mathrm{V}(\mathrm{t}) 2=\mathrm{Vf} 1+\mathrm{Vf} 2)$; Means followed by distinct letters differ statistically by Tukey's test $(\mathrm{P}<0.05)$. 
The high gas volumes from fiber carbohydrates were observed for the genotypes $N$. cochenillifera Salm Dyck (115.4 mL/g DM) and N. cochenillifera Dyck (121.7 mL/g DM) (P $=0.001$; Table 4). The N. cochenillifera Salm Dyck genotype showed the highest total gas production $(\mathrm{V}(\mathrm{t})$ - $341.1 \mathrm{~mL}$ and $\mathrm{V}(\mathrm{t}) 2-336.0 \mathrm{~mL})($ Table 4). Kd1 degradation rates were similar for all genotypes $(P=0.007$; Table 4$)$.

Cumulative gas production curves of the cactus pear genotypes showed a sigmoid shape (Figure 2), which is normally presented for the cumulative gas production curves in in vitro degradation studies. The curves were similar for all studied genotypes. It can be observed that, between 12 and 30 hours of fermentation, the cumulative gas production curves showed a decrease in the gas production, showing a tendency to stabilize after 30 hours of fermentation.
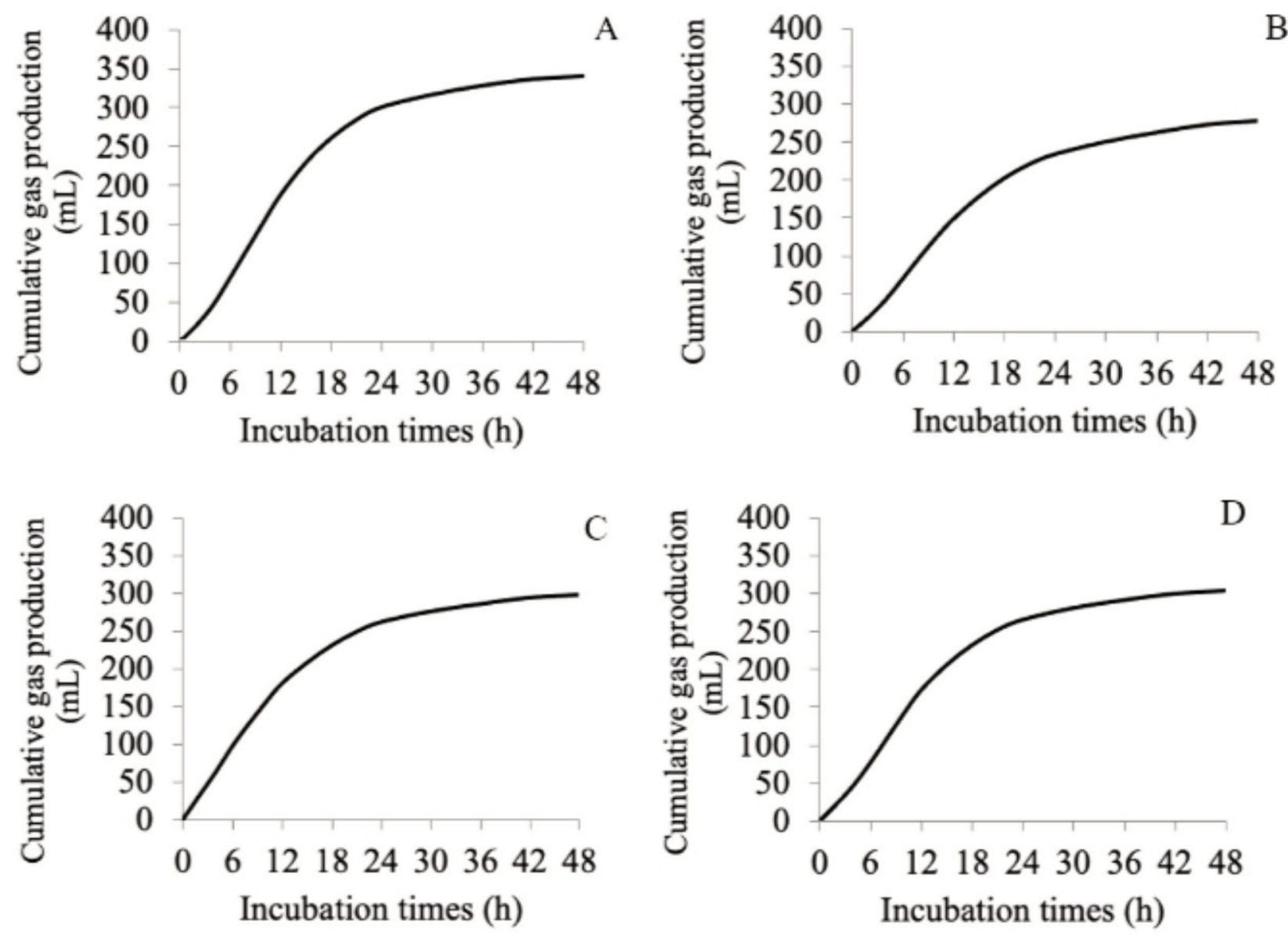

Figure 2. Cumulative gas production of cactus pear genotypes as a function of incubation time (A - Nopalea cochenillifera Salm Dyck; B - Opuntia ficus indica Mill; C - Opuntia stricta Haw; D - Nopalea cochenillifera Dyck).

\section{Discussion}

The cactus pear presents a chemical composition with low dry matter and protein contents and high carbohydrate contents ${ }^{(32)}$. Due to the low concentrations of DM in 
cactus pear, when there is a large supply of this food to animals, the DM requirements may be compromised. On the other hand, this characteristic represents a great contribution of water to the animals due to the high-water content that the cactus genus presents in its composition. This is beneficial for semiarid regions, which have water as a limiting factor for animal production ${ }^{(33)}$.

The cactus pear has a high mineral matter content due to a high concentration of macro-minerals, especially $\mathrm{Ca}$, primarily due to the presence of calcium oxalate

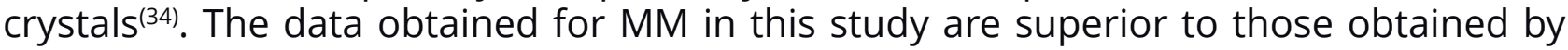
Silva et al. ${ }^{(35)}$, who found an average MM concentration of $11.9 \mathrm{~g} / \mathrm{kg}$ DM for the genus Opuntia and $11.7 \mathrm{~g} / \mathrm{kg}$ DM for the genus Nopalea and claimed that regardless of the genus, the cactus pear presents considerable amounts of MM. However these values vary according to the species, age of cladodes, geographic area, and time of the year.

In the $N$. cochenillifera Salm Dyck and O. ficus indica Mill genotypes, more than $300 \mathrm{~g} / \mathrm{kg}$ DM consists of pectin, which represents more than $50 \%$ of non-fibrous carbohydrates, while this value is $25.8 \%$ in the 0 . stricta Haw genotype, i.e., only half of the pectin present in N. cochenillifera Salm Dyck and O. ficus indica Mill was observed in this genotype. The pectin is a structural carbohydrate that is present in the cell wall. However, it is a soluble carbohydrate in neutral detergent, which is part of non-fibrous carbohydrates, having greater degradable potential by ruminal microorganisms. The high content of pectin in cactus pear genotypes was reported by Morales-Martínez et al. (36).

The fiber compounds of cactus pear, in general, are considered low for presenting contents of neutral detergent fiber below $250 \mathrm{~g} / \mathrm{kg}$ DM, which is a common feature among cacti, requiring association with a highly effective fiber source. The differences between the ADF of the cactus pear are explained by the quality of the carbohydrates present in these plants, which are an important energy source for ruminants that, according to Van Soest ${ }^{(37)}$, use it for the development of the microorganisms that colonize the rumen, mainly in the percentage of non-fibrous carbohydrates (sugar, starch, organic acids, and fructose) in the cell wall, which characterizes it as energetic food, besides that cactus pear presents good adaptability to the edaphoclimatic conditions of the region and high dry matter production per unit area.

For all tested genotypes, the TDN content was higher than $650 \mathrm{~g} / \mathrm{kg} \mathrm{DM}$, confirming the energy contribution of cactus pear for animal nutrition. The high DE and TDN contents of the different genotypes can be explained by the high levels of non-fiber carbohydrates, which are easily-digestible carbohydrates, such as starch and pectin.

Total carbohydrates constituted more than $75 \%$ of the DM content. Fractions A and B, containing over $90 \%$ of total carbohydrates, indicated that most of the carbohydrates are available for use by rumen microorganisms, confirming that all the studied genotypes present energy potential. In this study, the genotypes showed a low concentration of fraction $\mathrm{C}$, which may result in a high digestibility of fiber carbohydrates $^{(38)}$. Thus, the importance of carbohydrate fractions ingested by ruminants is based on the classification of rumen bacteria as for the use of carbohydrates forming plant cell walls and carbohydrates located in the cell content without structural functions ${ }^{(39-40)}$. 
Low crude protein content is a common feature of cacti. In the case of cactus pear, that is not a problem, since the CP content can be corrected by associating it with ingredients that are sources of true proteins and non-protein nitrogen (NPN). Of total protein, the fractions $A$ and $B$ account for approximately $80.0 \%$ in the genotypes $O$. ficus indica Mill, O. stricta Haw, and N. cochenillifera Dyck (Table 2). It can be stated that, although cactus pear is characterized by having a low protein concentration, a great amount of it is available for microbial degradation. The fraction C consists of proteins related to lignin, tannins, and products of the Maillard reaction, being highly resistant to microbial and enzymatic degradation. It is considered unusable both by the rumen and the intestines.

All genotypes showed high contents of soluble compounds due to a high content of fast-degrading carbohydrates in the rumen, in particular soluble sugars and pectin, which these plants have in their composition. For effective degradability, estimated according to slow, medium, and high passage rates, the highest values were estimated for the genotype 0 . stricta Haw. Even with a passing rate considered high, the effective degradability above $55 \%$ was observed, which is satisfactory. Such degradation potential is considered high as it is an estimation of degradability for all compounds that can be degraded during the incubation time. The high in vitro true DM digestibility of all genotypes studied is a reflection of high non-fiber carbohydrate contents and low lignin contents, which may explain the high rate of degradation of the slow-degrading DM fraction ${ }^{(41)}$.

All genotypes presented an IVTDMD of approximately $800 \mathrm{~g} / \mathrm{kg} \mathrm{DM}$, which is considered high. The high IVTDMD values observed in this study are partly related to the amount and quality of carbohydrates present in these genotypes, since more than $75 \%$ of the DM consisted of total carbohydrates and, out of these, more than $90 \%$ were considered potentially digestible according to carbohydrate fractions (Table 2). Confirming what was observed in this study, Gomez et al.(42) reported that high proportions of non-fiber carbohydrates, in general, increase the digestibility of cactus pear. This occurs as forages are readily degraded in the rumen, rapidly disappearing and increasing the energy supply. This favors microbial growth and hence digestion.

Moreover, the IVTNDFD confirms the high in vitro digestion of NDF fractions, which are also responsible for increasing the fiber digestibility of those varieties of cactus pear. The high IVTNDFD of the N. cochenillifera Salm Dyck and N. cochenillifera Dyck genotypes are highlighted. It is also noteworthy that such plants present a low lignin content $(<3 \%)$, which is a constituent of plant cells, with a low or null digestibility. Therefore, there were no slow-digesting fiber constituents in sufficient quantity, which could hinder the IVTDMD and IVTNDFD of these genotypes.

The low latency time of cactus pear is caused by its physical and chemical characteristics, since the soluble fraction is an energy substrate for fast-fermenting microorganisms, which facilitates the processes of substrate adhesion and colonization. This may increase the fermentation of fiber carbohydrates and reduce the latency time ${ }^{(8)}$.

The high gas production rate observed in the genotype N. cochenillifera Salm Dyck occurred as this genotype contains high contents of NFC and pectin. The large gas volumes from fiber carbohydrates can be explained by the high IVTNDFD of $N$. 
cochenillifera Salm Dyck and N. cochenillifera Dyck genotypes, as a more digestible NDF influences the gas production from fiber carbohydrates. Therefore, the fiber present in these two genotypes can be used by rumen microorganisms and generate high contents of energy for animals.

It is known that in vitro gas production results almost entirely from carbohydrates present in the incubated material and indicates degradation by rumen microorganisms. Thus, N. cochenillifera Salm Dyck showed the highest total gas production (341.14 mL/g DM). It is similar only to the genotype $N$. cochenillifera Dyck (303.4 mL/g DM); both belong to the same genus (Nopalea sp.) (Table 4). The higher content of total carbohydrates present in these genotypes, the low lignin content, and the low unavailable carbohydrate fractions (fraction C) justify the results observed. Furthermore, these same genotypes showed high IVTNDFD values, confirming that the technique of in vitro gas production can be used to estimate the quality of digestion of both non-fiber and fiber carbohydrates.

The adjustment of the two-compartment model for the generation of gas production parameters was considered the best as it separated the gas production from non-fiber and fiber carbohydrates, generating a degradation rate for each of these components. The adjustment of this model can be observed by the similarity of the actual values $(\mathrm{V}(\mathrm{t}))$ to the values estimated by the model $(\mathrm{V}(\mathrm{t}) 2)$. Thus, the two-compartment model is indicated for adjusting the in vitro gas production kinetics of the cactus pear genotypes studied.

\section{Conclusions}

The cactus pear genotypes show adequate chemical characteristics to be part of diets offered to ruminants. However, supplementation is necessary to increase the dry matter and fiber contents. The Nopalea cochenillifera Salm Dyck genotype presents the highest proportions of total digestible nutrients, non-fibrous carbohydrates, nonprotein nitrogen, total fraction of unavailable nitrogen, and high gas production rate in relation to the other analyzed genotypes at 24 months after field crop establishment.

\section{Conflict of interests}

The authors declare no conflict of interest.

\section{Acknowledgments}

Financial support of Bank of Northeastern Brazil (BNB) and Coordination for the Improvement of Higher Education Personnel (CAPES - Coordenação de Aperfeiçoamento de Pessoal de Nível Superior) in Brazil. 
Chemical composition, fractionation of carbohydrates and nitrogen compounds, ruminal degradation...

Magalhães A L R et al.

\section{References}

1. Alves FAL, Andrade AP, Bruno RLA, Santos DC, Magalhães ALR, Silva DS. Chemical and nutritional variability of cactus pear cladodes, general Opuntia and Nopalea. Am. J. Food Techn. 2017; 12(1):25-34. Disponível em: https://doi.org/10.3923/ajft.2017.25.34.

2. Alvalá RCS, Cunha APMA, Brito SSB, Seluchi ME, Marengo JA, Moraes OLL, Carvalho MA. Drought monitoring in the Brazilian Semiarid region. An. Acad. Bras. Ci. 2019; 9(1):e20170209. Disponível em: http://dx.doi.org/10.1590/0001-3765201720170209.

3. Magalhães ALR, Sousa DR, Nascimento Júnior JRS, Gois GC, Campos FS, Santos KC, Nascimento DB, Oliveira LP. Intake, digestibility and rumen parameters in sheep fed with common bean residue and cactus pear. Biol. Rhyt. Res. 2019a; 50(1): 1-11. Disponível em: https://doi.org/ 10.1080/09291016.2019.1592351.

4. Louhaichi M, Kumar S, Tiwari S, Islam M, Hassan S, Yadav OP, Dayal D, Moyo H, Dev R, Sarker A. Adoption and utilization of cactus pear in South Asia-Smallholder farmers' perceptions. Sustain. 2018; 10(10):1-15. Disponível em: https://doi.org/10.3390/su10103625.

5. Mendoza PV, Sousa TC, Santos MVF, Mendoza OVV, Dubeux Junior JCB, Lira MA. Organic matter fertilization improves morphological variables in Nopalea cochenillifera Salm Dyck cv. Miúda grown as forage in Pernambuco, Brazil. Rev. Mex. Ci. Pec. 2019; 10(3):756-766. Disponível em: https://doi.org/ 10.22319/rmcp.v10i3.4386.

6. Alves FAL, Santos DC, Silva SMS, Silva MC, Mello DR. Metabolismo fotossintético de variedades de palma forrageira cultivadas no Semiárido brasileiro. Pesq. Agropec. Pernamb. 2020; 25(2):e2262252020. Disponível em: https://doi.org/10.12661/pap.2020.009.

7. Matias AGS, Araújo GGL, Campos FS, Moraes SA, Gois GG, Silva TS, Emerenciano Neto JV, Voltolini TV. Fermentation profile and nutritional quality of silages composed of cactus pear and maniçoba for goat feeding. J. Agr. Sci. 2020; 158(4):1-9. Disponível em: https://doi.org/10.1017/S0021859620000581

8. Pinho RMA, Santos EM, Oliveira JS, Carvalho GGP, Silva TC, Macêdo AJS, Corrêa YR, Zanine AM. Does the level of forage neutral detergent fiber affect the ruminal fermentation, digestibility and feeding behavior of goats fed cactus pear? An. Sci. J. 2018; 89(10):1-8. Disponível em: https://doi.org/10.1111/asj.13043.

9. Cordova-Torres AV, Mendoza-Mendoza JC, Bernal-Santos G, García-Gasca T, Kawas JR, Costa RG, Jacobo $\mathrm{CM}$, Andrade-Montemayor HM. Nutritional composition, in vitro degradability and gas production of Opuntia ficus indica and four other wild cacti species. Life Sci. J. 2015; 12(2s):42-54. Disponível em: http:// dx.doi.org/10.7537/marslsj1202s15.07.

10. Magalhães ALR, Teodoro AL, Gois G.C., Campos, F.S., Souza, J.S.R., Andrade, A.P., Lima, I.E., Oliveira Lp, Nascimento DB. Chemical and mineral composition, kinetics of degradation and in vitro gas production of native cactus. J. Agric. Stud. 2019b; 7(4):129-137. Disponível em: https://doi.org/10.5296/ jas.v7i4.15315. 
Chemical composition, fractionation of carbohydrates and nitrogen compounds, ruminal degradation... Magalhães A L R et al.

11. Santos CB, Costa KAP, Souza WF, Silva VC, Epifanio OS, Santos HS. Protein and carbohydrates fractionation in Paiaguas palisade grass intercropped with grain sorghum in pasture recovery. Acta Scient. An. Sci. 2019; 41(1):1-8. Disponível em: https://doi.org/10.4025/actascianimsci.v41i1.42693.

12. Harun AY, Sali K. Factors affecting rumen microbial protein synthesis: A review. Veterinary Medicine Open J. 2019; 4(1):27-35. Disponível em: https://dx.doi.org/10.17140/VMOJ-4-133.

13. Köppen W, Geiger RG. Klimate der Erde. Gotha: Verlag Justus Perthes, Wall-map $150 \mathrm{~cm} \times 200 \mathrm{~cm}$. 1928.

14. Embrapa. Empresa brasileira de pesquisa agropecuária. Sistema brasileiro de classificação de solos, 5th ed. Brasília: Centro Nacional de Pesquisa de Solos; 2018. 356p. Portuguese.

15. Aoac. Association of Official Analytical Chemists. Official methods of analysis, 20th ed. Washington, D.C.: Latimer Jr., G.W.; 2016. 3172p.

16. Van Soest PJ, Robertson JB, Lewis BA. Methods for dietary fiber, neutral detergent fiber, and nonstarch polyssacharides in relation to animal nutrition. J. Dairy Sci. 1991; 74(10):3583-3597. Disponível em: https://doi.org/10.3168/jds.S0022-0302(91)78551-2.

17. Licitra G, Hernandez TM, Van Soest PJ. Standardization of procedures for nitrogen fracionation of ruminant feed. An. Feed Sci. Techn. 1996; 57(4):347-358. Disponível em: https://doi.org/ 10.1016/0377-8401(95)00837-3.

18. Mertens DR. Gravimetric determination of amylase-treated neutral detergent fiber in feeds with refluxing in beaker or crucibles: collaborative study. J. AOAC Int. 2002; 85(6):1217-1240. Disponível em: https://pubmed.ncbi.nlm.nih.gov/12477183/.

19. Silva DJ, Queiroz AC. Análise de alimentos: métodos químicos e biológicos, 3th ed. Viçosa: Editora UFV; 2006. 235p.

20. Canteri-Schemin MH, Fertonani HCR, Waszczynskyj N, Wosiacki G. Extraction of pectin from apple pomace. Braz. Arch. Biol. Techn. 2005; 48(2):259-66. Disponível em: http://dx.doi.org/10.1590/ S1516-89132005000200013.

21. Zanella K, Taranto OP. Influence of the drying operating conditions on the chemical characteristics of the citric acid extracted pectins from "pera" sweet orange (Citrus sinensis L. Osbeck) albedo and flavedo. J. Food Eng. 2015; 166(1):111-118. Disponível em: https://doi.org/10.1016/j.jfoodeng.2015.05.033.

22. Sniffen CJ, O'Connor JD, Van Soest PJ. A net carbohydrate and protein system for evaluating cattle diets: Il. Carbohydrate and protein availability. J. Anim. Sci. 1992; 70(11):3562-3577. Disponível em: https:/ /doi.org/10.2527/1992.70113562x.

23. Huhtanen $P$, Seppälä $A$, Ots $M$, Ahvenjärvi $S$, Rinne M. In vitro gas production profiles to estimate extent and effective first-order rate of neutral detergent fiber digestion in rumen. J. Anim. Sci. 2008; 86(3):651-659. Disponível em: https://dx.doi.org/10.2527/jas.2007-0246. 
Chemical composition, fractionation of carbohydrates and nitrogen compounds, ruminal degradation...

Magalhães A L R et al.

24. Nrc. Nutrient requirements of dairy cattle, 7th ed. Washington, D.C.: National Academy Press; 2001. $381 \mathrm{p}$.

25. Tilley JMA, Terry RA. A two-stage technique for the in vitro digestion of forage crops. J. Brit. Grass. Soc. 1963; 18(2):104-111. Disponível em: https://onlinelibrary.wiley.com/doi/abs/10.1111/ j.1365-2494.1963.tb00335.x.

26. Holden LA. Comparison of methods of in vitro dry matter digestibility for ten feeds. J. Dairy Sci. 1999; 82(8):1791-1795. Disponível em: https://dx.doi.org/10.3168/jds.S0022-0302(99)75409-3.

27. Ørskov ER, McDonald I. The estimation of protein degradability in the rumen from incubation measurements weighted according to rate of passage. J. Agr. Sci. 1979; 92(2):499-503. Disponível em: https://doi.org/10.1017/S0021859600063048.

28. Afrc. Agricultural and Food Reaserch Council. Energy and protein requirements of ruminants. Wallingford: CAB International; 1993.159p.

29. Theodorou MK, Williams BA, Dhanoa MS, Mcallan AB, France J. A simple gas production method using a pressure transducer to determine the fermentation kinetics of ruminant feeds. An. Feed Sci. Techn. 1994; 48(3-4):185-197. Disponível em: https://doi.org/10.1016/0377-8401(94)90171-6.

30. Schofield P, Pitt RE, Pell AN. Kinetics of fiber digestion from in vitro gas production. Journal of Animal Science. 1994; 72(11):2980-2991. Disponível em: https://doi.org/10.2527/1994.72112980x.

31. Sas. Statistical analysis system institute. SAS/STAT User's guide, version 9.3. Cary: SAS Institute; 2011.

32. Al-Arif MA, Suwanti LT, Estoepangestie ATS, Lamid M. The nutrients contents, dry matter digestibility, organic matter digestibility, total digestible nutrient, and $\mathrm{NH}_{3}$ rumen production of three kinds of cattle feeding models. KnE Life Sci. 2017; 36(6):338-343. Disponível em: https://doi.org/10.18502/kls.v3i6.1142.

33. Pessoa DV, Andrade AP, Magalhães ALR, Teodoro AL, Santos DC, Araújo GGL, Medeiros AN, Nascimento DB, Valença RL, Cardoso DB. Forage cactus of the genus Opuntia in different with the phenological phase: Nutritional value. J. Arid Env. 2020; 181(104243):1-8. Disponível em: https://doi.org/ 10.1016/j.jaridenv.2020.104243.

34. Toit A, Wit M, Hugo A. Cultivar and harvest month influence the nutrient content of Opuntia spp. cactus pear cladode mucilage extracts. Mol. 2018; 23(4):1-12. Disponível em: https://doi.org/10.3390/ molecules 23040916

35. Silva APG, Souza CCE, Ribeiro JES, Santos MCG, Pontes ALS, Madruga MS. Physical, chemical and bromatological characteristics of the giant forage cactus (Opuntia ficus-indica) and small forage cactus (Nopalea cochenillifera) from Paraíba state (Brazil). Rev. Bras. Tec. Agroind. 2015; 9(2):1810-1820. Disponível em: https://doi.org/10.3895/rbta.v9n2.1616

36. Morales-Martínez Y, López-Cuellar MR, Chavarría-Hernández N, Rodríguez-Hernández Al. Rheological behaviour of acetylated pectins from cactus pear fruits (Opuntia albicarpa and O. matudae). Food 
Chemical composition, fractionation of carbohydrates and nitrogen compounds, ruminal degradation... Magalhães A L R et al.

Hydrocol. 2018; 85(1):110-119. Disponível em: https://doi.org/10.1016/j.foodhyd.2018.07.009.

37. Van Soest PJ Mertens DR. Nutritional ecology of the ruminant, 2nd ed. Cornell University Press: Ithaca. 1994; $476 \mathrm{p}$.

38. Singh BS, Bhat V, Shukla GP, Singh KK, Gehrana D. Variation in carbohydrate and protein fractions, energy, digestibility and mineral concentrations in stover of sorghum cultivars. Trop. Grass. 2018; 6(1):4252. Disponível em: https://doi.org/10.17138/TGFT(6)42-52.

39. Deusch S, Camarinha-Silva A, Conrad J, Beifuss U, Rodehutscord M, Seifert J. A structural and functional elucidation of the rumen microbiome influenced by various diets and microenvironments. Front. Microb. 2017; 8(1):1-21. Disponível em: https://doi.org/10.3389/fmicb.2017.01605.

40. Williams BA, Grant LJ, Gidley MJ, Mikkelsen D. Gut fermentation of dietary fibers: Physico-chemistry of plant cell walls and implications for health. Int. J. Mol. Sci. 2017; 18(10):1-25. Disponível em: https:// doi.org/10.3390/ijms18102203.

41. Doorenbos J, Martín-Tereso J, Dijkstra J, Van Laar H. Effect of different levels of rapidly degradable carbohydrates calculated by a simple rumen model on performance of lactating dairy cows. J. Dairy Sci. 2017; 100(7):5422-5433. Disponível em: https://doi.org/10.3168/jds.2016-12278.

42. Gómez LM, Posada SL, Oliveira M. Starch in ruminant diets: a review. Rev. Colomb. Ci. Pec. 2016; 29(2):77-90. Disponível em: https://dx.doi.org/10.17533/udea.rccp.v29n2a01. 